\title{
The Cell Biology of Neuroblastoma
}

\author{
John B. Denny \\ Department of Ophthalmology \\ University of Texas Health Science Center,San Antonio \\ Texas \\ USA
}

\section{Introduction}

Neuroblastoma is the third most common solid tumor in children and is the most common extracranial solid tumor in children (Maris, 2010; Coulter et al., 2008; Wickstrom et al., 2007). It is highly malignant and has a poor outcome despite aggressive treatment, even with autologous stem cell transplantation (Sartelet et al., 2008). It is a disease of the neural crest and the sympathetic nervous system, and most often originates from the adrenal gland. Neuroblastoma occurs as low risk, medium risk, and high risk forms, with the high risk form being difficult to treat even with the most advanced protocols. The prognosis for neuroblastoma is poor in advanced stages of the disease. Low risk forms may regress spontaneously, and may require no surgery and only observation (Kitanaka et al., 2002). Spontaneous remission occurs more commonly in neuroblastoma than in other cancers (Carlsen, 1990; Hero et al., 2008). The reasons for this are not at present understood. The overall cure rate is $40 \%$, which indicates that new therapeutic strategies are needed (Sartelet et al., 2008). This chapter will focus on the cell and molecular biology of neuroblastoma, and the development of therapeutic strategies for its treatment. It will emphasize biologically unfavorable and clinically aggressive neuroblastomas rather than biologically favorable neuroblastomas.

\section{Cancer cell growth}

Tumor cells require the action of growth factors to proliferate. The initial step is the interaction of growth factors and cytokines with various receptors, followed by the subsequent activation of other signaling molecules. Neuroblastic (N-type) cells are the predominant cell type in neuroblastoma, as oppoed to stromal (S-type) cells (Armstrong et al., 2006).

\subsection{Growth factors binding to Receptor Tyrosine Kinases (RTKs)}

Receptor tyrosine kinases (RTKs) are transmembrane proteins that contain tyrosine kinase activity and include the receptor for insulin, the receptor for IGF-1 (insulin-like growth factor-1), called IGF1R, the TrkA high affinity receptor for nerve growth factor (NGF), the eph receptors for the neuronal guidance factors known as ephrins, the TrkB receptor for brain-derived neurotrophic factor (BDNF), and the receptors for the acidic and basic forms 
of fibroblast growth factor (FGF), GDNF (glial cell line-derived neurotrophic factor), VEGF (vascular endothelial growth factor), PDGF (platelet-derived growth factor), and EGF (epidermal growth factor) (Sartelet et al., 2008). NGF binding to TrkA causes the neuronal growth-associated protein GAP-43 to become phosphorylated by protein kinase $\mathrm{C}$ in isolated growth cones (Denny, 2006). NGF causes an increase in the production of GAP-43 by PC12 cells (Denny, 2006). RTKs activate PI3K (phosphatidylinositol 3-kinase), which leads to activation of the protein kinase Akt. The IGF1R has been implicated in the pathogenesis of neuroblastoma (Coulter et al., 2008). IGF1R signals through the Ras/Raf/MEK(mitogen-activated protein kinase)/ERK(extracellular signal-regulated kinase) pathway to induce proliferative growth and through the PI3K/Akt pathway for anti-apoptosis (Coulter et al., 2008). BDNF/TrkB are expressed in cases of neuroblastoma that have a poor prognosis (Jaboin et al., 2002; Li and Thiele, 2007). BDNF/TrkB protects neuroblastoma cells from chemotherapy-induced apoptosis (Jaboin et al., 2002). This is mediated by the PI3K/Akt pathway, making Akt a target to improve the prognosis ( $\mathrm{Li}$ and Thiele, 2007). BDNF/TrkB also prevents axotomized retinal ganglion cell death, by acting through the MAPK and PI3K pathways (Nakazawa et al., 2002). The specific inhibitors LY294002 (PI3K) and U0126 (MAPK) were used (Nakazawa et al., 2002). The gene for the transcription factor MYCN is amplified in approximately $20 \%$ of human neuroblastomas and gives a poor prognosis (Petroni et al., 2011). MYCN overexpression sensitizes neuroblastoma cells to apoptosis, which requires the phosphorylation of p53 at Ser-46 by the protein kinase HIPK2 (Petroni et al., 2011). MYCN expression is disrupted when the IGF1R is blocked by a specific antibody, $\alpha$ IR3 (Coulter et al., 2008). N1E-115 neuroblastoma cells produce GAP-43 when they are differentiated by low serum and dimethylsulfoxide (DMSO) (Ollom and Denny, 2008).. It has been proposed that when NCAM on a growth cone encounters a suitable substrate, FGF receptors are clustered and GAP-43 is phosphorylated at Ser- 41 by protein kinase $C$, leading to cytoskeletal changes and growth cone advance. (Denny, 2006).. The expression of GAP-43 in neuroblastoma cells suggests that the cells are attempting to function as neurons by extending growth cones and neurites.The expression of GAP-43 by differentiated N1E-115 cells is particularly intense (Ollom and Denny, 2008; Baker and Storm, 1997), whereas its expression in the retinal ganglion cell line RGC-5 is much weaker (Ollom and Denny, unpublished results). Differentiation of N1E-115 cells also causes the up-regulation of angiotensin II receptors (Reagan et al., 1990). The N1E-115 cells were differentiated by the presence of $0.5 \%$ serum and 1.5\% DMSO (Reagan et al., 1990). These cells incorporated radioactive palmitate into GAP-43, but the palmitoylated protein was only immunoprecipitated by an antibody directed toward the C-terminal 10 amino acids of GAP-43 (Ollom and Denny, unpublished results). The presence of the palmitate chains may block the binding of antibodies at other sites in the protein. Protein palmitoylation in N1E-115 cells was not affected by norepinephrine, Sema3A, or netrin-1. GAP-43 was crosslinked to calmodulin but not to actin following analysis by twodimensional electrophoresis (Ollom and Denny, 2008). Full-length GAP-43 phosphorylated at Ser-41 was immunoprecipitated from differentiated N1E-115 cells with an antibody specific for that phosphorylated residue, and a $34 \mathrm{kDa}$ fragment containing that epitope was detected on Western blot. Nogo-A is a transmembrane protein that was initially thought to block nerve regeneration through its expression on oligodendrocytes, but it has been shown to be expressed on N1E-115 cells and SH-SY5Y cells (Liu et al., 
2002) as well as on normal hippocampal neurons (Zagrebelsky et al., 2010). Melatonin protected neuroblastoma cells, acting as cultured neurons, from the effects of Alzheimer amyloid peptide (Pappolla et al., 1997)

\subsection{Cytokines}

Cytokines include tumor necrosis factor- $\alpha$ (TNF- $\alpha$ ), TNF- $\beta$, interleukins, and interferons (IFNs). They bind to receptors other than RTKs. TNF- $\alpha$ causes inflammation and kills tumor cells in vitro. It can be administered to patients as an anti-cancer agent, but has not been successful due to its toxicity and the development of resistance. The binding of IL-3 (interleukin-3) to its receptor activates Raf/MEK/ERK, PI3K/Akt, and JAK/STAT (Janus kinase/ Signal Transducer and Activator of Transcription), which results in cell proliferation and prevention of apoptosis (Steelman et al., 2004). Bacterial products cause macrophages to release TNF- $\alpha$ and IL-12, which cause NK (natural killer) cells to release interferon- $\gamma$ (IFN- $\gamma$ ). This interferon in turn causes macrophages to secrete more TNF- $\alpha$ and IL-12. IFN- $\gamma$ is the only type II interferon. It is produced by NK cells, NKT (natural killer T) cells, and by CD4 (cluster of differentiation 4) T helper cells and CD8 cytotoxic T cells. IFN- $\gamma$ is the main factor that causes macrophage activation. It also activates cytotoxic T cells and NK cells. T helper cells secrete many interleukins which include IL-2, -3, -4, -5, and -6. Activated macrophages can kill both parasites and cancer cells. The secretion of IL-12 and TNF- $\alpha$ by macrophages is inhibited by IL-10. Human type I interferons include IFN- $\alpha$ and IFN- $\beta$, which inhibit neuroblastoma angiogenesis and growth (Streck et al., 2004) and are secreted by NK cells, Bcells, T-cells, fibroblasts, endothelial cells, macrophages, and osteoblasts. They stimulate an anti-viral response in both NK cells and macrophages. Alpha IFNs slow the rate of tumor cell division until the cells can no longer survive, and can also increase the level of IL-6. The commercially available alpha IFN Intron-A (interferon alfa-2b) is currently used to treat hairy cell leukemia, bladder cancer, chronic myelogenous leukemia (CML), ovarian cancer, multiple myeloma, malignant melanoma, non-Hodgkins lymphoma (NHL), and Kaposi's sarcoma, but not, as yet, neuroblastoma. Both type I and type II interferons contain approximately 166 amino acids and bind to the type II cytokine receptor. The IFNs can increase Class I and Class II major histocompatability complex (MHC) antigen expression. IFN- $\gamma$ increases the expression of Class I MHC antigens on neuroblastoma cells, increasing the likelihood of infiltration of T cells into the tumor in vivo (Reid et al., 2009). One of the most common means by which solid tumor cells evade the immune response is by downregulation of Class I MHC antigen expression (Garcia-Lora, et al., 2003) IL-6 promotes the survival of neuroblastoma cells in bone marrow (Ara al., 2009). It has been suggested by Robert Seeger and Yves DeClerck that inflammation may promote neuroblastoma. Consistent with this is the finding that TNF functions as a growth factor for neurob;astoma (Goillot et al., 1992). C1300 neuroblastoma cells retrovirally transduced with the IL-4 gene had reduced tumorigenicity in syngeneic $\mathrm{A} / \mathrm{J}$ and nude mice when compared with wild type cells (Yoshida et al., 1998).

\subsection{G-Protein coupled receptors}

G-protein coupled receptors (GPCRs) are proteins that cross the plasma membrane seven times and act through heterotrimeric G-proteins, which are active in the GTP-bound state and inactive in the GDP-bound state. The rate of cell division can be increased by G-protein stimulation of PI3K and Ras, and also by activation of phospholipase C (PLC), which leads to the formation of diacylglycerol (DAG) and the activation of protein kinase $C$ (PKC). PKC 
is also stimulated by calcium and phosphatidylserine. Another source of DAG is phosphatidylcholine, utilizing the enzyme phospholipase D (PLD) (Denny, 2006). PKC then activates Raf and the Raf/MEK/ERK pathway, leading to cell division. PKC also activates the transcription factor NF-KB (nuclear factor-KB), which affects transcription in the nucleus. There are six catecholamine receptors and include D1, D2, $\beta 1, \beta 2, \alpha 1$, and $\alpha 2$. All six receptors are GPCRs. Adenylate cyclase (AC) is stimulated by $D_{1}$ dopamine receptors and inhibited by $\mathrm{D}_{2}$ receptors. The $\beta$ receptors both activate AC. $\alpha 1$ receptors constrict arterioles and raise blood pressure, and $\alpha 2$ receptors are located presynaptically on neurons in the vasomotor center of the brainstem. Clonidine, acting as an agonist at these $\alpha 2$ receptors, lowers the concentration of norepinephrine in the plasma, thereby lowering blood pressure. When epinephrine or norepinephrine bind to the $\beta$-adrenergic receptor (either $\beta_{1}$ or $\beta_{2}$ ), the stimulatory G-protein Gs is activated, which then activates adenylate cyclase, leading to the formation of cAMP and the activation of protein kinase A (PKA). This leads to the activation of the transcription factor CREB (cAMP response element-binding), which alters gene expression in the nucleus. A different G-protein activates guanylate cyclase, leading to the formation of cGMP. The binding of acetylcholine to the muscarinic acetylcholine receptor activates PLC and PKC. The muscarinic receptor can also interact with the inhibitory Gprotein $\mathrm{Gi}$, leading to an inhibition of adenylate cyclase. The metabotropic glutamate receptor and the receptors for many peptides in the brain, including angiotensin II, are GPCRs (Denny et al., 1991) . GPCR activation of PI3K does not always lead to cell division but can cause an increase in neurite outgrowth instead. Angiotensin II, binding to the angiotensin type I receptor and stimulating the PI3K/Akt pathway, caused an increase in the expression of the growth-associated protein GAP-43 and neurite outgrowth rather than an increase in the rate of cell division (Yang et al., 2002). Both GAP-43 and the G-protein Go are found in high concentrations in neuronal growth cones (Denny, 2006).

A cyclic nucleotide phosphodiesterase (PDE) breaks down the cyclic nucleotides cAMP and cGMP. The PDE inhibitors Zaprinast and DC-TA-46 inhibit SK-N-MC neuroblastoma growth, both in vitro and in a xenograft model of nude mice (Giorgi et al., 2001). The concentrations for $50 \%$ inhibition (IC50 values) in clonal density experiments were $3.3 \mu \mathrm{M}$ and $1.9 \mu \mathrm{M}$, respectively.

\subsection{Integrins}

Integrins are heterodimeric transmembrane proteins that activate focal adhesion kinase (FAK) and the tyrosine kinase Src. Src phosphorylates FAK, and FAK then activates Ras. Like Src, FAK is a tyrosine protein kinase. Integrins also activate the Rho GTPase Cdc42. Integrins bind extracellular matrix molecules such as laminin. Cancer cells become invasive and lose their ability to be guided by the extracellular matrix. GAP-43 is phosphorylated at Ser-41 by protein kinase C when laminin binds to its integrin (Lalli and Hall, 2005), which shows the activating effect of the extracellular matrix on neurons in culture. GAP-43 is expressed in neurons as a result of prostate cancer, and causes axon sprouting (JimenezAndrade et al., 2010). Other proteins present intracellularly at the integrin site include talin, vinculin, paxillin, F-actin, and microtubules.

\subsection{Ras}

The Ras superfamily contains $21 \mathrm{kDa}$ monomeric GTPases that are important in many aspects of normal cell function. The Ras superfamily contains a subfamily also called Ras, 
which is involed in cell proliferation. Subfamily Rho is important in neuronal development (Denny, 2006). This subfamily controls the dynamics of the cytoskeleton and includes the GTPases RhoA, RhoB, RhoC, RhoD, RhoF, RhoG, Cdc42 and Rac-1. Rac-1 promotes the formation of the actin-rich lamellipodium that surrounds the central core of the growth cone in growing neurons. From the lamellipodium are formed actin-containing filopodia. The formation of filopodia is promoted by Cdc42 (Denny, 2006). Other subfamilies include Rab (involved in membrane trafficking), Ran (a single member involved in nuclear transport), Arf (involved in vesicular transport), and Rheb (Ras homolog enriched in brain). Rheb functions in cell proliferation as described below. The Ras subfamily contains H-Ras, K-Ras, N-Ras, R-Ras, TC21 (R-Ras2), Rap1A, Rap1B, Rap2A, Rap2B, RalA, RalB, and M-Ras (RRas3) (Denny, 2006, 2008; Kimmelman et al., 2002). Ral GTPases have been shown to regulate neurite branching via GAP-43 and in this way contribute to cell growth (Lalli and Hall, 2005). Point mutations in the genes H-ras, K-ras, or $\mathrm{N}$-ras can give rise to protein products which can transform NIH-3T3 cells to a fully malignant phenotype (Gutierrez and Magee, 1991). These cells exhibit transformed characteristics in culture but are inhibited by tumor suppressor mechanisms when injected into wild-type mice. This suppression is overcome when the cells are injected into athymic (nude) mice, and tumors develop (Chambers et al., 1990). The activated form of Ras proteins binds GTP and the unactivated form binds GDP. A mutation can diminish the GTPase activity and cause Ras to remain in the GTP-bound form. Such a mutation in Ras will lock the Raf/MEK/ERK pathway in the "on" position and contribute to the cell becoming cancerous.

\subsection{Lipid modifications of proteins}

Palmitoylation refers to the addition of the 16 carbon fatty acid palmitate to proteins, primarily in reversible thioester linkage to cysteine (Denny, 2008). Many proteins involved in cell growth and division are palmitoylated, including GPCRs, heterotrimeric G-protein $\alpha$ subunits, monomeric GTPases, GAP-43, integrins, and NCAM (neural cell adhesion molecule)-140 and NCAM-180 (Denny, 2008). The Src family of protein tyrosine kinases include Src, Lyn, Yes, Lck, and Fyn. Lyn is palmitoylated while c-Src (cellular Src) is not (Kasahara et al., 2007). Src was found not to be palmitoylated while Yes, Lck, and Fyn were palmitoylated and myristoylated (Koegl et al., 1994). Myristoylation refers to the addition of the 14 carbon fatty acid myristate to the $\mathrm{N}$-terminus of a protein in permanent amide linkage. Heterotrimeric G-protein $\alpha$-subunits are palmitoylated and myristoylated (Denny, 2008). Ras proteins are modified by both palmitoylation and prenylation, the latter involving the addition of either the 15 carbon farnesyl group or the 20 carbon geranylgeranyl group (Denny, 2008). These modifications are required for the activity of Ras (Denny, 2008). Blockade of the farnesylation of Ras is a therapeutic approach in cancer (Margaritora, et al., 2005; Omer et al., 1997), as is the blockade of geranylgeranyltransferase I (Philips and Cox, 2007).

\subsection{PI3K/PTEN/Akt/mTOR pathway}

The serine/threonine protein kinase Akt (also called protein kinase B) lies at the center of a pathway that promotes cancer cell survival and protects cells from apoptosis (Sartelet et al., 2008). Pathological activation of Akt frequently occurs in neuroblastoma and correlates with a poor prognosis (Fulda, 2009). Phosphatidylinositol 3-kinase (PI3K) converts the phospholipid phosphatidylinositol 4,5 bisphosphate (PI $(4,5)$ P2 or PIP2) to 
phosphatidylinositol 3,4,5 triphosphate (PI $(3,4,5)$ P3 or PIP3). PIP3 causes the protein kinase PDK1 to bind to the plasma membrane and phosphorylate Akt at Thr-308. PI3K is heterodimeric with an $85 \mathrm{kDa}$ regulatory subunit and a $110 \mathrm{kDa}$ catalytic subunit. Full activation of Akt occurs following a second phosphorylation at Ser-473, which is carried out by mTORC2 (Martelli et al., 2010), as described below. PI3K is the initial molecule to be activated by RTKs, GPCRs, and Ras. The oncogenic version of Ras requires an interaction with PI3K to produce its transforming effect (Carnero et al., 2008). Inhibition of Akt by the inhibition of PI3K has been studied, as well as drugs, such as geldanamycin and rapamycin, that modify the expression of Akt (Sartelet et al., 2008). The blockade of Akt signaling has been shown to result in apoptosis and growth inhibition of tumor cells (Tokunaga et al., 2008). Phosphorylated Akt phosphorylates and thereby inhibits TSC2, which is a GAP (GTPase activating protein) that together with TSC1 inactivates the small GTPase Rheb. When TSC2 is inhibited, Rheb accumulates in the GTP-bound form. This form activates the protein kinase activity of mTORC1, leading to activation of the protein kinase p70S6K and phosphorylation of ribosomal protein S6. This pathway leads to decreased apoptosis, and increased cell metabolism, proliferation, ribosome biogenesis, and translation (Martelli et al., 2010). Phosphorylated Akt activates MDM2, which inhibits p53. Since p53 promotes the apoptosis of tumor cells, this constitutes another mechanism whereby activated Akt inhibits apoptosis and promotes cancer growth (Martelli et al., 2010). The inhibition of Akt appears to be an excellent future course for the treatment of neuroblastoma (Sartelet et al., 2008).

The mammalian target of rapamycin (mTOR) is a $289 \mathrm{kDa}$ serine/threonine protein kinase that regulates cell-cycle progression, autophagy, and cell survival, and was discovered as the binding site for rapamycin (Sarbassov et al., 2005). It is a single chain of 2,549 amino acids. Rapamycin binds to the $12 \mathrm{kDa}$ protein FKBP12, and this complex binds to and inhibits mTOR (Marelli et al., 2010). The kinase domain of mTOR is located toward the Cterminus, between residues 2181 and 2431 (Martelli et al., 2010). Two complexes exist that contain mTOR, called mTORC1 and mTORC2 (Martelli et al., 2010). Both complexes contain the protein deptor (Peterson et al., 2009; Martelli et al., 2010). In normal cells, deptor holds mTORC1 and mTORC2 in check, helping to prevent transformation to the cancerous phenotype. In most cancers the expression of deptor is low, which allows mTORC1 and mTORC2 kinase activities to promote cell growth and survival and convert the cell to the cancerous phenotype. A major mechanism in this regard is the direct activation of Akt by mTORC2. By contrast, mTORC1 inhibits the activating pathways upstream of Akt. Treating cells with rapamycin, which binds to mTORC1, therefore leads to Akt activation, and may limit the usefulness of rapamycin and its analogs as anti-cancer drugs (Peterson et al., 2009). Nevertheless, the inhibition of the IGFR combined with rapamycin or temsirolimus inhibited the growth of the neuroblastoma cell lines BE-2 (c) and IMR-32 (Coulter et al., 2008). In contrast to most cancers, a subset of multiple myelomas that contain translocations in cyclinD1/D3 or c-MAF/MAFB contain highly overexpressed deptor, and its inhibition of mTORC1 unexpectedly leads to the activation of the PI3K/mTORC2/Akt pathway (Peterson et al., 2009). A decrease in deptor levels in these cells leads to apoptosis (Peterson et al., 2009). Inhibitors of mTOR are being used to treat advanced renal cell carcinoma (Kapoor and Figlin, 2009).

\subsection{Raf/MEK/ERK pathway}

Raf is a serine/threonine protein kinase that is coded for by the c-raf proto-oncogene. The Raf/MEK/ERK pathway is located downstream of Ras. Mutations in Ras can cause the 
Raf/MEK/ERK pathway to be permanently activated, leading to the formation of cancer cells (Steelman et al., 2008). The activation of this pathway leads to the activation of the transcription factor Fos. It also leads to the activation of $c-j u n \mathrm{~N}$-terminal kinases (JNKs) which activate the transcription factor Jun. The combination of Fos and Jun is called AP-1.

\subsection{JAK/STAT pathway}

This pathway can also be activated by mutated Ras (Steelman et al., 2008). The binding of cytokines to their receptors activates a JAK (Janus Kinase), which undergoes autophosphorylation by tyrosine kinase activity. The phosphorylated form of JAK binds seven different STATs (Signal Transducer and Activator of Transcription), which are transcription factors which enter the nucleus, bind to seven different promoters, and alter gene expression. In the cytosol, a STAT can stimulate Bcl-xL. This is anti-apoptotic, since Bcl-xL blocks the activating effect of mitochondrial cytochrome $\mathrm{c}$ on caspase-9. Interferon- $\beta$ induces apoptosis in the SH-SY5Y cell line through activation of JAK/STAT signaling and down-regulation of the PI3K/Akt pathway (Dedoni et al., 2010). Apoptosis was accompanied by the cleavage of caspases $-9,-7$, and -3 , cytochrome c release, and the phosphorylation of STAT1 (Dedoni et al., 2010). IL-6 promotes the survival of neuroblastoma cells in bone marrow (Ara al., 2009). IL-6 and IL-10 contribute to neuroblastoma progression, with IL-6 acting through STAT3 (Song et al., 2007).

\subsection{Anaplastic Lymphoma Kinase (ALK)}

The gene for anaplastic lymphoma kinase (ALK) is the major gene that predisposes an individual to familial neuroblastoma (Maris, 2010; Mosse et al., 2008). Although ALK is important in the normal development of the brain, the mutation of its gene is associated with 10-15\% of neuroblastomas (Mosse et al., 2008). ALK, also known as CD246, is a novel receptor tyrosine kinase and its inhibition is an approach in cancer therapy (Mosse et al., 2009).

\subsection{Cytogenetic alterations in neuroblastoma}

The outlook in neuroblastoma, as it is in other cancers, is better if the patient possesses a normal karyotype. The above pathways may become activated as a result of cytogenetic alterations, in which parts of chromosomes are deleted and added or translocated to other chromosomes. This places promoters near genes that they would normally not affect, and this increases the likelihood of converting a proto-oncogene to an oncogene. In the highest risk form of neuroblastoma the cells contain cytogenetic alterations such as MYCN amplification or $1 p$ deletion (Wickstrom et al., 2007). The $6 \mathrm{p} 22$ locus is associated with clinically aggressive neuroblastoma (Maris et al., 2008). By contrast, the gain of whole chromosomes occurs most commonly in biologically favorable neuroblastomas, as the gain of chromosome 17 is the most frequent abnormality detected in neuroblastoma (Plantaz et al., 1997).

How chromosomal translocations result in cancer has been studied in B-cells. Translocation of the $c-m y c$ gene close to the enhancer for antibody heavy chains yields cancerous B-cells in Burkitt's lymphoma (Adams and Cory, 1998). Myc is a transcription factor and its major effect is on B- cell proliferation. MYCN codes for a member of the Myc family that is specifically associated with neuroblastoma. In cancerous B-cells, the part of chromosome 18 containing the $b c l-2$ locus undergoes a reciprocal translocation with the part of chromosome 
14 that contains the antibody heavy chain locus. This is a $t(14: 18)$ translocation, which places the $b c l-2$ gene close to the heavy chain gene enhancer. All of the resulting leukemias are called chronic lymphocytic leukemia (CLL). Because Bcl-2 is pro-survival and is now expressed at a high level, it prevents apoptosis, which should normally occur in the B-cell once an infection has passed. This causes the B-cell to continue to divide and to become cancerous. More than just the translocation is necessary, however, since $50 \%$ of the population contains the above B-cell translocation but the individuals do not have cancer. This shows that it is possible for an individual to have cancer cells but not have cancer.

\subsection{NBPF10}

NBPF10 (neuroblastoma breakpoint family member 10) has its gene in humans located at 1q21.1. It is highly conserved and contains DUF1220 repeats. It is thought to be related to the $1 \mathrm{q} 21.1$ deletion syndrome and the 1q21.1 duplication syndrome.

\subsection{Angiogenesis and neuroblastoma}

Angiogenesis in neuroblastoma has been reviewed (Ribatti et al., 2004). Imatinib has been used on neuroblastoma tumorigenesis and vascular endothelial growth factor (VEGF) expression (Beppo et al., 2009).Tumors increase vascularization to provide a greater blood supply. Lenalidomide (Revlimid) is related to thalidomide and possesses immunomodulatory and antiangiogenic properties. It inhibits the secretion of proinflammatory cytokines and promotes the release of anti-inflammatory cytokines from peripheral blood mononuclear cells. It decreases the activity of TNF- $\alpha$. Lenalidomide blocks the proliferation of some cancer cell lines but not others. Lenalidomide blocks growth factorinduced angiogenesis and growth factor-induced endothelial cell migration, which may be due to an inhibition of Akt phosphorylation (Dredge et al., 2005). It also blocks the basic fibroblast growth factor (bFGF)-induced increase in the phosphorylation of Akt in vitro (Dredge et al., 2005). It is currently used in the treatment of multiple myeloma but could have use in neuroblastoma.

\subsection{Neuroblastoma-derived cell lines}

The cell line N1E-115 is one of many clones that were derived from the spontaneous mouse neuroblastoma C-1300 (Amano et al., 1972). The growth of cell lines in serum-free medium containing the growth factors insulin, transferrin, progesterone, putrescine, and sodium selenite was pioneered using the rat neuroblastoma cell line B104 (Bottenstein and Sato, 1979). When N1E-115 cells are placed in serum-free medium and are thereby deprived of growth factors, they stop dividing and develop neuronal characteristics, rather than undergo apoptosis (Baker and Storm, 1997). A marked increase in the level of GAP-43 is seen following the differentiation of N1E-115 cells (Denny, 2006; Ollom and Denny, 2008). By contrast, most cancer cells undergo apoptosis when deprived of growth factors (Kilic et al., 2002). The main executioner caspase was caspase-3 in apoptosis induced by serum starvation in AKR-2B fibroblasts (Kilic et al., 2002). An apoptosome of molecular weight 600 $\mathrm{kDa}$ was formed and free activated caspase-12 was detected in the cytosol (Kilic et al., 2002). No cleavage of caspase-9 was detected (Kilic et al., 2002).

SH-SY5Y cells were derived from a human neuroblastoma, show neuronal characteristics, and respond to the application of norepinephrine (Laifenfeld et al., 2002). Norepinephrinetreated SH-SY5Y cells showed alterations in the expression of 44 genes, as determined in a 
neurobiology cDNA microarray (Laifenfeld et al., 2002). The expression of the genes for GAP-43, the cell adhesion molecule L1, and laminin were increased (Laifenfeld et al., 2002).

Neurons grow, using Akt, but in the sense of extending axons instead of creating daughter cells. Axonal growth is channeled through tissues during development without disrupting them, while invasion of tissue by cancer cells is disruptive and may result in the death of the host. The semaphorin Sema3A inhibits neurite outgrowth by inhibiting the phosphorylation of Akt (Chadborn et al., 2006).

We have found that the protein kinase inhibitor staurosporine is lethal for N1E-115 cells when applied to undifferentiated cells (C.M. Ollom and J.B. Denny, unpublished results). By contrast, it causes the retinal ganglion cell line RGC-5 to differentiate into neuronal-like cells (Lieven et al., 2007). In addition, staurosporine causes the differentiation of SH-SY5Y cells (Prince and Oreland, 1997). One explanation for these results is that N1E-115 cells lack sufficient Bcl-2 to prevent the apoptosis that is induced by staurosporine. Bcl-2 has been shown to be protective against the cytotoxic effects of staurosporine (Takeda et al., 1997). By contrast, either low serum (Baker and Storm, 1997) or low serum and dimethylsulfoxide (Ollom and Denny, 2008) cause N1E-115 cells to stop dividing and to undergo neurite extension. Growth has been switched in these cases from abnormal cell division to a more normal neurite extension. How does this switch occur? Why do these cancer cells not undergo apoptosis when deprived of growth factors in low serum? N1E-115 cells appear to have retained many genes, especially those involved in cytoskeletal dynamics, that allow neurite extension to occur (Oh, et al., 2006). N1E-115 cells were differentiated by the addition of dimethylsulfoxide, and most of the pathways described above were involved in the differentiation process, including protein kinases A and C, TrkA, B. and C, MAP kinases, raf kinases, ERK, and c-jun N-terminal kinases (Oh et al., 2005, 2006).

\section{Tumor suppression}

\subsection{PTEN (Phosphatase and Tensin Homolog)}

A point mutation in an oncogene may not result in cancer, because a second event may be required, such as the inhibition of NK cell function or the mutation of the gene for PTEN, which will raise the level of PIP3 in the cell and allow the activation of Akt. If normal PTEN is present, it may nullify the mutation in Ras by decreasing the level of PIP3 to the point that Akt cannot be continuously activated. PTEN (phosphatase and tensin homolog) carries out the reverse reaction of PI3K and thereby decreases the level of PIP3 in the cell. This decreases the amount of activated Akt and reduces the ability of the cell to divide. Mutations in the PTEN gene are associated with many human cancers. A small fraction of neuroblastomas were found to harbor PTEN alterations when 45 primary neuroblastoma tumors and 12 neuroblastoma cell lines were screened (Munoz et al., 2004). The level of activated Akt is therefore determined by the level of PI3K, which promotes its formation, and by the level of PTEN, which decreases its formation.

\section{$3.2 \mathrm{p} 53$}

p53 is encoded by the TP53 gene located on the short arm of chromosome 17 in humans. Human p53 contains 393 amino acids. The protein can activate DNA repair mechanisms and arrest cells prior to the entrance into $S$ phase of the cell cycle to allow this repair to occur. If the DNA damage is not repairable, p53 initiates apoptosis of the cell. If p53 is altered by 
mutation, the block for cells entering $S$ phase will not occur, and cells will divide uncontrollably, leading to cancer. Tumor suppression is therefore greatly reduced if the TP53 gene is altered. Mutations in p53 were reported to be infrequent in neuroblastoma (Tweddle et al., 2003). The protein p73 has been shown to cause the differentiation of a neuroblastoma cell line (De Laurenzi et al., 2000). P73 and p63 are related to p53.

\subsection{Selenium and vitamin $\mathrm{E}$ as anti-oxidants}

Selenium is a cofactor for glutathione peroxidase, which uses glutathione to decrease the levels of hydrogen peroxide and organic hydroperoxides in the cell. Vitamin E has a similar anti-oxidant role. Epidemiological studies suggest that selenium may protect against cancer. Anti-oxidants were neuroprotective in SH-SY5Y cells overexpressing the familial Parkinson's disease alpha-synuclein A53T mutation (Ma et al., 2010). DHA (docosahexaenoic acid) is the most abundant polyunsaturated fatty acid in the retina and has neuroprotective effects against oxidative stress in retinal ganglion cells.

\subsection{DNA repair and tumor suppression}

NF1 is a tumor suppressor in neuroblastoma that controls the response to retinoic acid and the disease outcome (Holzel et al., 2010). NF1 codes for the protein neurofibromin, which is an enzyme controlling Ras. Loss of NF1 activates Ras-MEK signaling, and neuroblastomas with low levels of NF1 and ZNF423 have an extremely poor outcome (Holzel et al., 2010). NF1 regulates TSC2 and mTOR. A repressible DNA repair system exists in mouse neuroblastoma cells (McCombe and Kidson, 1975). MicroRNA-542-5p has been shown to be a novel tumor suppressor in neuroblastoma (Bray et al., 2011). DNA repair can contribute to tumor suppression by repairing mutated sites in the genome that can lead to cancer. A common example is the removal of thymine dimers that are formed each day in skin cells as a result of exposure to the UV-B wavelength band of UV light from the sun. The presence of these dimers can result in a mutation that may lead to skin cancer if not removed. The enzyme carrying out DNA repair in the nuclear genome in humans is DNA polymerase $\beta$, while that acting on the mitochondrial genome is DNA polymerase $\gamma$. The repair activity in mitochondria is much less efficient than that occurring in the nucleus, leading to a much greater rate of mutation in the mitochondrial genome compared to the nuclear genome. The loss of this thymine dimer excision is clearly a loss of tumor suppression.

\subsection{The immune response}

There is ample evidence that cancer cells cause an immune response in the host. Immunodeficiency leads to an increased likelihood of cancer, as in the development of Kaposi's sarcoma in patients infected with the human immunodeficiency virus (HIV). In addition, there is an increase in Epstein-Barr virus (EBV)-induced lymphoma in transplant patients. Finally, the fact that neuroblastoma can regress spontaneously suggests that immunological mechanisms can come into play (Carlsen, 1990). If the tumor cell load is reduced by chemotherapeutic agents, it is possible that the immune system can control the residual tumor. Without immune system attack, those tumor cells that escape chemotherapeutic agents can regrow and kill the host. It may be necessary for the tumor cell load to be low for the immune system to control or destroy the cells that evaded attack by chemotherapeutic agents. The immune response to neuroblastoma has been increased by increasing the immunogenicity of neuroblastoma cells using IL-2 (Bowman et al., 1998). 


\subsection{Natural Killer (NK) cells}

Natural killer (NK) cells are lymphocytes that kill certain neuroblastoma cells lines in culture (Ogbomo et al., 2006). The cell lines were UKF-NB-2 and UKF-NB-4 obtained from bone marrow metastases of neuroblastoma patients with stage IV disease (Ogbomo et al., 2006). NK cells are inhibited by alcohol (Boyadjieva et al., 2004), which could be a factor in the onset of neuroblastoma in children born to mothers who consumed alcohol during pregnancy. The inhibition of NK cells could alone account for the carcinogenic properties of alcohol. NK cells are tumoricidal without the need for Class I MHC antigen participation.

\subsection{Tumor Specific Transplantation Antigens (TSTAs) and Tumor Associated Transplantation Antigens (TATAs)}

Tumor cell antigens that can induce this immune response include tumor specific transplantation antigens (TSTAs), which are unique to the tumor cell, are not expressed on normal cells, and are responsible for tumor rejection. Tumor associated transplantation antigens (TATAs) are expressed by both tumor cells and normal cells. Although antibodies may develop against TSTAs, cell-mediated immunity appears to be most important in tumor rejection. Activated macrophages can, in addition, be tumoricidal.

This response has been called immune surveillance. Does immune surveillance prevent the formation of many cancers and why does it sometimes fail? It is possible that the TSTAs may not be sufficiently immunogenic to elicit the required immune response, or the cells may not express sufficient Class I MHC antigens, or they may secrete antigens that block antibody and cell-mediated responses. Tumor cells can escape immune detection by downregulating Class I MHC molecules, which decreases the detection of TSTAs. Antibodies may bind to NK cells, B-lymphocytes, macrophages, and granulocytes without binding to the tumor cells. All of this constitutes an escape from immune surveillance, which allows the tumor cells to proliferate. Neuroblastoma cells are of neuroectodermal origin and express a number of cancer germline (CG) antigens (Wolfl et al., 2005). Screening of 68 tumor specimens for CG antigens revealed expression of MAGE-A1 in 44\%, MAGEA3/A6 in 21\%, and NY-ESO-1 in 28\% of cases (Wolfl et al., 2005). None of the selected tumors showed expression of MHC class I or class II antigens, which would limit the immunogenicity of the tumors in the host.

\subsection{Antibody treatment of neuroblastoma}

Antibodies directed toward the disialoganglioside GD-2, located on the cell surface, have been used in the treatment of neuroblastoma (Navid, et. al., 2010; Cheung et al., 1998). This ganglioside is not widely expressed on normal cells, making it an attractive target for antibody therapy in neuroblastoma and other cancers. Treatment of high risk neuroblastoma with antibody to GD-2 and the cytokines GM-CSF (granulocyte-macrophage colony-stimulating factor) and IL-2 gave superior outcomes when compared to treatment with six cycles of isotretinoin (Yu et al., 2010).

\section{Cancer cell apoptosis}

An important approach in cancer treatment is to modulate the apoptosis of cancer cells. Programmed cell death (PCD) can be either caspase-dependent (apoptosis) or caspaseindependent (Kang et al., 2004). Neuronal PCD occurs normally in brain development but 
also occurs in pathological states. The PCD of cancer cells is a desirable end point in terms of either curing a patient's cancer or decreasing the cancer cell load. Although NGF is a growth factor when it binds to TrkA, it can cause apoptosis when it binds to the low affinity receptor p75NTR (Wang et al., 2001).

\subsection{Caspases}

The caspases are cysteine-dependent, aspartate-directed proteases, and make up a family of 14 enzymes, termed caspases 1-14 (Kang et al., 2004). Only seven of these participate in apoptosis. These include the initiator caspases $-2,-8,-9$, and -10 and the effector or executioner caspases $-3,-6$, and -7 . Caspase- 8 expression is thought to be silenced in most high stage neuroblastomas (Hopkins-Donaldson et al., 2002). Interestingly, caspase-3 participates in long-term depression (LTD) and AMPA receptor internalization, giving the enzyme a broader role in the nervous system than simply being an executioner caspase involved in apoptosis (Zheng et al., 2010).

\subsection{Death receptors}

The binding of the ligands TNF- $\alpha$, FasL, and TRAIL (TNF-related apoptosis-inducing ligand) to their receptors TNFR (TNF receptor), Fas, and DR4 or DR5, respectively, termed death receptors of the TNFR superfamily, induces apoptosis (Kang et al., 2004). The binding of TRAIL to DR4 or DR5 induces rapid apoptosis. Caspases-2, -3 , and -7 have been shown to be involved in thapsigargin-induced apoptosis of SH-SY5Y cells (Dahmer, 2005). Fas is also known as Cluster of Differentiation 95 or CD95. FasL is therefore also called CD95L.

\subsection{Bcl-2}

The Bcl-2 family of cytoplasmic proteins contains three subfamilies (Adams and Cory, 1998). Proteins most like Bcl-2 itself promote cell survival, while those more distantly related promote apoptosis. The fate of the cell is thus a result of the balance between these two types of proteins. Bcl stands for B-cell leukemia or B-cell lymphoma. The first subfamily is also called Bcl-2. It is pro-survival and anti-apoptotic, and includes the proteins Bcl-2, Bcl$\mathrm{xL}, \mathrm{Bcl}-\mathrm{w}, \mathrm{Mcl}-1$, and A1. By contrast, the Bax subfamily is pro-apoptotic and includes the proteins Bax, Bak, and Bok. Bax is stimulated by p53, which promotes apoptosis. The BH3 subfamily is also pro-apoptotic and includes the proteins Bad, Bid, Bik, Blk, Hrk, BNIP3, and BimL. Akt inhibits Bad and thereby inhibits apoptosis and promotes growth. Bcl-2 is a 25 $\mathrm{kDa}$ protein with a C-terminal hydrophobic section of 21 amino acids that is important for docking to the cytoplasmic face of the mitochondrial membrane. Its gene $b c l-2$ is also a proto-oncogene. The Fas (CD95/APO-1/TNFRSF6) receptor-ligand system is one of the key regulators of apoptosis. Fas is triggered by binding to its ligand FasL, either as membranebound FasL on FasL-expressing cells or through the crosslinking of soluble FasL. Fas then recruits Fas-associated death domain protein (FADD) and procaspase- 8 to form the deathinducing signaling complex (DISC), which activates the caspase cascade, causing cell death (Kischkel et al., 1995). It has been shown that palmitoylation is required for efficient Fas cell death signaling (Chakrabandhu et al., 2007). The binding of norepinephrine and other $\alpha$ agonists to $\alpha-1$ adrenergic receptors blocks neuronal cell death associated with glutamateinduced excitotoxicity, and does so in the retinal ganglion cell line RGC-5 by regulating calcium and Bax levels and the activation of caspase-3 (Tchedre and Yorio, 2008). Bcl-2 is a regulator for retinoic-acid induced apoptotic cell death in neuroblastoma (Niizuma et al., 
2006). Cell lines that downregulated Bcl-2 (CHP134 and NB-39-nu cells) underwent apoptosis in the presence of all-trans-retinoic acid (ATRA), whereas those cell lines highly expressing Bcl-2 (LA-N-5 cells and RTBM1 cells) underwent differentiation instead of apoptosis (Niizuma et al., 2006).

\subsection{Nitric Oxide}

Nitric oxide (NO) is produced from L-arginine and molecular oxygen by nitric oxide synthase (NOS) isotypes that include neuronal NOS (nNOS), inducible NOS (iNOS), and endothelial NOS (eNOS) (Kang et al., 2004). Neuronal NOS mRNA was detected in four of nine human neuroblastoma cell lines (Fujisawa et al., 1994). A shorter mRNA was also detected (Fujisawa et al., 1994). Nitric oxide binds to the heme moiety of soluble guanylate cyclase, activating the enzyme and thereby stimulating the conversion of GMP to cGMP. At low levels, NO protects cells from apoptosis that is induced by growth factor deprivation, whereas stimulation of NMDA receptors by glutamate yields high levels of NO by activating nNOS via calcium/calmodulin, which leads to neuronal apoptosis (Kang et al., 2004; Denny, 2006). NO prevents the serum deprivation-induced apoptosis of SH-SY5Y cells by increasing the expression of cytoprotective genes such as thioredoxin (Andoh et al., 2002) and thioredoxin peroxidase, and cGMP may play a role in this increase in gene expression (Kang et al., 2004).

By contrast, nitric oxide induced apoptosis in SH-SY5Y cells (Moriya, et al., 2000). NO caused the cleavage of the short peptides DEVD-AFC, VDVAD-AFC, and LEHD-AFC, which are substrates for caspases -3 , and -7 , caspase-2, and caspase-9, respectively (Moriya et al., 2000). Each substrate contains one or two aspartic acid residues. The pro forms of caspases -2, -3, -6, and -7 decreased during apoptosis (Moriya et al., 2000). There was a subsequent loss of mitochondrial membrane potential (Moriya et al., 2000). Paclitaxel also induced the apoptosis of SH-SY5Y cells, an effect that was inhibited by trans-resveratrol (Nicolini et al., 2001).

\section{Chemotherapy}

The previous information presented in this chapter will now be applied to chemotherapeutic agents that have been used in the treatment of neuroblastoma. Twelve drugs are currently indicated for the treatment of neuroblastoma: carboplatin, cisplatin, cyclophosphamide, dacarbazine, doxorubicin, etoposide, fenretinide, iobenguane, isotretinoin, melphalan, teniposide, and vincristine. Only three of these, cyclophosphamide, doxorubicin, and vincristine, are FDA-approved for this use at present. The remaining nine drugs are being used experimentally in neuroblastoma therapy, as are bleomycin, bortezomib, and dexamethosone. Iobenguane is currently FDA-approved only for imaging purposes.

\subsection{Alkylating agents}

The alkylating agents cyclophosphamide (Cytoxan), melphalan (Alkeran), and BCNU (bischloroethylnitrosourea), also called Carmustine, have two alkyl chloride groups capable of reacting with the nucleophilic nitrogen atom at position seven of guanine, yielding crosslinking of adjacent DNA strands. Dacarbazine is also thought to act as an alkylating agent. These reactions cause DNA strand scission, which blocks replication and 
transcription and results in cell death. All of these agents have shown activity against neuroblastoma. Chlorambucil is an alkylating agent with a structure similar to melphalan but is mainly used to treat CLL. BCNU inhibited the growth of the SK-N-MC neuroblastoma (Giorgi et al., 2001). Melphalan is used for stem cell transplant preparation in neuroblastoma. High dose melphalan, with stem cell support, has been used in the treatment of advanced neuroblastoma (Pritchard et al., 2005). It consolidates the response to induction chemotherapy (Pritchard et al., 2005). The melphalan prodrug J1 (L-melphalanylp-L-fluorophenylalanine ethyl ester) displayed high cytotoxic activity in vitro against seven neuroblastoma cell lines, with IC50 values in the submicromolar range (Wickstrom et al., 2007). J1 induced caspase-3 cleavage and apoptotic morphology, had additive effects with doxorubicin, cyclophosphamide, carboplatin, and vincristine, and killed otherwise drugresistant cells when combined with etoposide (Wickstrom et al., 2007). Also susceptible to J1 were athymic rats and mice carrying neuroblastoma xenografts containing SH-SY5Y and SK-N-BE(2) cells (Wickstrom et al., 2007).

Of all the alkylating agents, cyclophosphamide stands at the forefront of therapy in neuroblastoma. The most commonly used induction chemotherapy regimen includes doseintensive cycles of cisplatin and etoposide alternating with vincristine, doxorubicin, and cyclophosphamide (Kushner, et al., 1994).

\subsection{Doxorubicin}

Doxorubicin is also called Adriamycin, and the liposomal form is called Doxil. Doxorubicin, but not Doxil, is FDA-approved for the treatment of neuroblastoma. Doxorubicin intercalates between the bases of DNA, changing its geometry and causing a cytotoxic effect. Doxorubicin also produces cytotoxicity by interacting with topoisomerase II. Doxorubicininduced death in stromal or S-type cells in neuroblastoma does not involve death receptors such as Fas and is caspase-independent in N-type cells (Hopkins-Donaldson et al., 2002). Doxorubicin was applied to the caspase- 8 silenced N-type invasive neuroblastoma cells lines LAN-1 and IMR-32 and to the S-type noninvasive SH-EP neuroblastoma cells expressing caspase-8 (Hopkins-Donaldson et al., 2002). Doxorubicin induced caspase-3, -7, -8, and -9 and Bid cleavage in S-type cells and death was blocked by caspase inhibitors. Doxorubicintreated S-type cells showed apoptotic nuclei while N-type cells did not (Hopkins-Donaldson et al., 2002). Both doxorubicin and cisplatin were found to activate caspase- 9 and caspase- 3 but not caspase-8 in S-type cells (Bian et al., 2004). The central effect of caspase-9 was augmented by the expression of CD95/Fas (Bian et al., 2004).

\subsection{Fenretinide}

Fenretinide (4-hydroxy(phenyl)retinamide) is a synthetic retinoid that is used in the treatment of neuroblastoma. It may cause the accumulation of a ceramide and reactive oxygen species in tumor cells, causing cell death via apoptosis (Wu et al., 2001).

\subsection{Isotretinoin}

Isotretinoin is a retinoid, which resembles vitamin A and is a mediator of cell proliferation and apoptosis. The retinoid receptors are part of the steroid-thyroid superfamily of nuclear receptors called retinoid X receptors (RXRs) and retinoic acid receptors (RARs) (Denny, 2006). Isotretinoin acts mainly on RARs. Isotretinoin is part of the standard therapy during the first remission in patients with high-risk neuroblastoma (Maris, 2010). 


\section{5 lobenguane}

Iobenguane (metaiodobenzylguanidine, MIBG) containing radioactive iodine (131I) is currently being used experimentally to destroy tumor cells in relapsed or high-risk neuroblastoma (Howard et al., 2005). K. Matthay has used this compound along with vorinostat to incrase its effectiveness in neuroblastoma. Vorinostat is a histone deacetylase inhibitor that sensitizes neuroblastoma to radiation. ${ }^{131} \mathrm{I}$ is primarily a beta emitter but about $10 \%$ of its radiation output is gamma radiation. Iobenguane iodinated with ${ }^{123}$ I or ${ }^{131}$ I has been used in imaging. ${ }^{123} \mathrm{I}$ is a gamma emitter, but at the energy primarily used for imaging, rather than for the destruction of cells. Iobenguane resembles norepinephrine and is therefore concentrated in adrenergic tissue. This allows for the diagnosis and therapy of both neuroblastoma and pheochromocytoma.

\subsection{Carboplatin, Cisplatin, Bleomycin, Etoposide, and Vincristine}

Cisplatin (CDDP; cis-diamminedichloroplatinum (II)) interacts electrostatically with the same nucleophilic nitrogen atom in guanine that reacts with the alkylating agents. As with alkylating agents, this generates DNA crosslinks. Cisplatin also binds to nitrogen at the seven position in adenine. Increased DNA repair overcomes the effect of cisplatin, generating resistance. The chlorine atoms are replaced by the 1,1-cyclobutanedicarboxylato ligand in carboplatin. Bleomycin acts by forming a complex with DNA. If this cytotoxic action is repaired, the anti-cancer effect of the drug is blocked and resistance occurs. Etoposide binds to a complex of DNA and topoisomerase II, which is cytotoxic. Teniposide functions similarly to etoposide Bleomycin was used in conjunction with etoposide and cisplatin in the treatment of adult neuroblastoma arising from the broad ligament of the uterus (Milam et al., 2007). The patient died 20 months after diagnosis (Milam et al., 2007). Cisplatin, vinblastine, and bleomycin (CVB) have been used in the treatment of relapsed, disseminated neuroblastoma (Bostrom et al., 1984).

\subsection{Bortezomib}

Bortezomib (Velcade) is an effective inhibitor of neuroblastoma cell growth and angiogenesis (Combaret et al., 2008). The drug is used in the treatment of multiple myeloma (Combaret et al., 2008). Bortezomib inhibits the action of the $26 \mathrm{~S}$ proteasome, which is a large protease complex located in the cytosol and nucleus. The action of the $20 \mathrm{~S}$ proteasome on GAP-43 was studied in vitro (Denny, 2004). If the proteasome degradation of the proteins p21cip, p27kip, and cyclins is inhibited, the cells are sensitized to apoptosis (Martelli et al., 2010). An advantage for bortezomib is that cancer cells are much more sensitive to proteasome inhibition than are normal cells. This is in contrast to alkylating agents, which have considerable cytotoxic effects on both normal and cancer cells, causing hair loss due to the action of the drugs on normal cells in the hair follicles. Carfilzomib is a second generation proteasome inhibitor for the treatment of multiple myeloma.

Bortezomib inhibits the activation of NF-KB by stabilizing its inhibitor protein IKB. Activation of NF-KB results in the production of VEGF, which promotes angiogenesis, interleukin-6, VCAM-1 (vascular cell adhesion molecule-1), and anti-apoptotic factors such as Bcl-2. VCAM-1 is also called CD106. It causes the adherence of malignant plasma cells to bone marrow stromal tissue in multiple myeloma. Bortezomib links the death receptor to the mitochondrial pathway in neuroblastoma cells, which leads to TRAIL-induced apoptosis (Naumann et al., 2011). Bortezomib enhances the TRAIL-induced cleavage of Bid into tBid, accumulation of $\mathrm{tBid}$ in the cytosol, and insertion of $\mathrm{tBid}$ into the mitochondrial membrane (Naumann et al., 2011). Bortezomib stabilizes tBid, promoting apoptosis (Naumann et al., 
2011). Our results with staurosporine and N1E-115 cells are consistent with the proposed mechanism of action of bortezomib. If the proteasomal degradation of IKB is blocked by bortezomib, IKB is present to block NF-KB and less Bcl-2 is produced, leading to an increased susceptibility of the cancer cells to apoptosis.

\subsection{PI-103}

PI3K is inhibited by Wortmannin and LY294002, and mTOR is inhibited by rapamycin, but it has been found that inhibiting PI3K and mTOR at the same time with the drug PI-103 is more effective in the treatment of T-cell acute lymphoblastic leukemia (T-ALL) than is the inhibition of PI3K and mTOR separately (Chiarini et al., 2009). PI-103 induced the apoptosis of T-ALL cells that was characterized by the activation of caspase- 3 and caspase- 9 (Chiarini et al., 2009). A similar approach may be fruitful in neuroblastoma.

\subsection{Treatment with glucocorticoids}

Although the glucocorticoids betamethasone, dexamethasone, prednisolone, and prednisone inhibit tumor cell growth and are used in the treatment of many cancers, they are presently not indicated in the treatment of neuroblastoma. However, consistent with its anti-cancer effect, dexamethasone has been found to block the migration of the human neuroblastoma cell line SK-N-SH (Casulari et al., 2006). A study sponsored by the Children's Oncology Group and the National Cancer Institute (NCI), with ClinicalTrials.gov identifier NCT00033293 and entitled "Cyclophosphamide and prednisone with or without immunoglobulin in treating abnormal muscle movement in children with neuroblastoma", is recruiting participants in 2011.

\section{Concluding remarks}

New treatment modalities are needed for neuroblastoma, which continues to have an overall cure rate of only $40 \%$. Promising approaches include those involving immunotherapy, with antibodies directed toward the GD-2 antigen. The use of interferons, used currently in other cancers, also shows promise, with their inherent stimulation of the tumoricidal effects of NK cells and activated macrophages. The combination of immunotherapy and conventional chemotherapy and radiotherapy utilizing iobenguane and radioactive iodine appear to be useful approaches. The use of isotretinoin and fenretinide, as well as bortezomib and lenalidomide, may be helpful in this disease. The inhibition of the protein kinases Akt, mTOR, and ALK, which lie at the center of the abnormalities of the neuroblastoma cell, may prove very fruitful. Promotion of the effect of PTEN, which counters the effect of Akt, is also a useful approach. It is clearly important to initiate the apoptosis of neuroblastoma cells. The use of existing neuroblastoma cell lines and the cloning of new cell lines will continue to be a very useful research technique for the development of new therapies. Many new treatment options now exist and will be forthcoming for a very serious disease that affects such a young population.

\section{Acknowledgments}

This work was supported by a grant from the San Antonio Area Foundation and by an unrestricted grant to the Department of Ophthalmology from Research to Prevent Blindness (RPB), New York, NY. 


\section{References}

Adams, J.M., and Cory, S. (1998) The Bcl-2 protein family: Arbiters of cell survival. Science 281(5381):1322-1326.

Amano, T., Richelson, E., and Nirenberg, M. (1972) Neurotransmitter synthesis by neuroblastoma clones. Proc. Natl. Acad. Sci. USA 69(1):258-263.

Andoh, T., Chock, O.B., and Chiueh, C.C. (2002) The roles of thioredoxin in protection against oxidative stress-induced apoptosis in SH-SY5Y cells. J. Biol. Chem. 277(12): 9655-9660.

Ara, T., Song, L., Shimada, H., Keshelava, N., Russell, H.V., Metelitsa, L.S., Groshen, S.G.Seeger, R., and DeClerck, Y.A. (2009) Interleukin-6 in the bone marrow microenvironment promotes the growth and survival of neuroblastoma cells. Cancer Res. 69:329-337.

Armstrong, M.B., Bian, X., Liu, Y., Subramanian, C., Ratanaproeska, A.B., Shao, F., Yu, V.C., Kwok, R.P.S., Opipare, Jr., A.W., Castle, V.P. (2006) Signaling from p53 to NF-kB determines the chemotherapy responsiveness of neuroblastoma. Neoplasia 8(1): 967977.

Baker, L.P., and Storm, D.R. (1997) Dynamic palmitoylation of neuromodulin (GAP-43) in cultured rat cerebellar neurons and mouse N1E-115 cells. Neurosci. Lett. 234(2-3): 156-160.

Beppu, K., Jaboine, J., Marchant, M.S., Marshal, C.S., and Thiele, C.S. (2003) Effect of imatinib mesylate on neuroblastoma tumorigenesis and vascular endothelial growth factor expression. J. Natl. Cancer Insti.86(1):46-55.

Bian, X., Giordano, T.D., Lin, H.J., Solomon, G., Castle, V.P., and Opipari, A.W., Jr. (2004) Chemotherapy-induced apoptosis of S-type neuroblastoma cells requires caspase-9 and is augmented by CD95/Fas stimulation. J. Biol. Chem. 279(6): 4663-4669.

Bostrom, B., Woods, W.G., Ramsay, N.K., Krivit, W., Levine, P., and Nesbit, M.E., Jr. (1984) Cisplatin, vinblastine, and bleomycin (CVB) therapy for relapsed disseminated neuroblastoma. Cancer Treat. Rep. 68(9):1157-1158.

Bottenstein, J.E., and Sato, G.H. (1979) Growth of a rat neuroblastoma cell line in serum-free supplemented medium. Proc. Natl. Acad. Sci. USA 76(1):514-517.

Bowman, L., Grossmann, M., Rill, D., Brown, M., Zhong, W.Y., Alexander, B., Leimig, T., Coustan-Smith, E., Campana, D., Jenkins, J., Woods, D., Kitchingman, G., Vanin, E., and Brenner, M. (1998) IL-2 adenovector-transduced autologous tumor cells induce antitumor immune responses in patients with neuroblastoma. Blood 92(6):19411949.

Boyadjieva, N.I., Chaturvedi, K., Poplawski, M.M., and Sarkar, D.K. (2004) Opioid antagonist naltrexone disrupts feedback interaction between $\mu$ and $\delta$ opioid receptors in splenocytes to prevent alcohol inhibition of NK cell function. $J$. Immunol. 173: 42-49.

Bray, I., Tivnan, A., Bryan, K., Foley, N.H., Watters, K.M., Tracey, L., Davidoff, A.M., and Stallings, R.L. (2011) MicroRNA-542-5p as a novel tumor suppressor in neuroblastoma. Cancer Lett. 303(1): 56-64.

Carlsen, N.L. (1990) How frequent is spontaneous remission of neuroblastoma? Implications for screening. Br. J. Cancer 61:441-446. 
Carnero, A., Blanco-Aparicio, C., Renner, O., Link, W., and Leal, J.F. (2008) The PTEN/PI3K/AKT signalling pathway in cancer therapeutic implications. Curr. Cancer Drug Targets 8: 187-198.

Casulari, L.A., Dondi, D., Maggi, R., Demissie, M., Piccolella, M., and Piva, F. (2006) Dexamethasone blocks the migration of the human neuroblastoma cell line SK-NSH. Braz. J. Med. Biol. Res. 39(9): 1233-1240.

Chadborn, N.H., Ahmed, A.I., Holt, M.R., Prinjha, R., Dunn, G.A., Jones, G.E., and Eickholt, B.J. (2006) PTEN couples Sema3A signalling to growth cone collapse. J. Cell Sci. 119: 951-957.

Chakrabandhu, K., Herincs,, Z., Huault, S., Dost, B., Peng, L., Conchonaud, F., Marguet, D., He, H.-T., and Hueber, A.-O. (2007) Palmitoylation is required for efficient Fas cell death signaling. EMBO J. 26: 209-220.

Chambers, A.F., Denhardt, G.H., and Wilson, S.M. (1990) Ras-transformed NIH 3T3 cell lines, selected for metastatic ability in chick embryos, have increased proportions of p21-expressing cells and are metastatic in nude mice. Invasion Metastasis 10(4): 225240.

Cheung, N.K., Kushner, B.H., Yeh, S.D., and Larson, S.M. (1998) 3F8 monoclonal antibody treatment of patients with stage 4 neuroblastoma: a phase II study. Int. J. Oncol. 12(6):1299-1306.

Chiarini, F., Fala, F., Tazzari, P.L., Ricci, F., Astolfi, A., Pession, A., Pagliaro, P., McCubrey, J.A., and Martelli, A.M. (2009) Dual inhibition of class IA phosphatidylinositol 3kinase and mammalian target of rapamycin as a new therapeutic option for T-cell acute lymphoblastic leukemia. Cancer Res. 69(8): 3520-3528.

Combaret, V., Boyault, S., Iacono, I., Brejon, S., Rousseau, R., and Puisieux, A. (2008) Effect of bortezomib on human neuroblastoma: analysis of molecular mechanisms involved in cytotoxicity. Mol. Cancer 7: 50-61.

Coulter, D.W., Blatt, J., D'Ercole, A.J., and Moats-Staats, B.M. (2008) IGF-1 receptor inhibition combined with rapamycin or temsirolimus inhibits neuroblastoma cell growth. Anticancer Res. 28: 1509-1516.

Dahmer, M.K. (2005) Caspases-2, -3 , and -7 are involved in thapsigargin-induced apoptosis of SH-SY5Y neuroblastoma cells. J. Neurosci. Res. 80: 576-583.

De LaurenziV., Raschella, G., Barcaroli, D., Annicchiarico-Petrazzelli, M., Ranalli, M., Catani, M.V.Tanno, B., Constanzo, A., Levrero, M., and Melino, G. (2000) Induction of neuronal differentiation by p73 in a neuroblastoma cell line. J Biol. Chem. 275(20): 15226-15231.

Dedoni, S., Olianas, M.C., and Onali, P. (2010) Interferon- $\beta$ induces apoptosis in human SHSY5Y neuroblastoma cells through activation of JAK-STAT signaling and downregulation of PI3K/Akt pathway. J. Neurochem. 115(6): 1421-1433.

Denny, J.B. (2004) Growth-associated protein of $43 \mathrm{kDa}$ (GAP-43) is cleaved nonprocessively by the 20 S proteasome. Eur. J. Biochem. 271: 2480-2493.

Denny, J.B. (2006) Molecular mechanisms, biological actions, and neuropharmacology of the growth-associated protein GAP-43. Curr. Neuropharm. 4: 293-304.

Denny, J.B. (2008) Protein palmitoylation in neuronal growth and plasticity. Curr. Top. Peptide E Protein Res. 9: 57-69.

Denny, J.B., Polan-Curtain, J., Wayner, M.J., and Armstrong, D.L. (1991) Angiotensin II blocks hippocampal long-term potentiation. Brain Res. 567: 321-324. 
Dredge, K., Horsfall, R., Robinson, S.P., Zhang, L.H., Lu, L., Tang, Y., Shirley, M.A., Muller, G., Schafer, P., Stirling, D., Dalgleish, A.G., and Bartlett, J.B. (2005) Orally administered lenalidomide (CC-5013) is anti-angiogenic in vivo and inhibits endothelial cell migration and Akt phosphorylation in vitro. Microvasc. Res. 69: 5663.

Fujisawa, H., Ogura, T., Kurashima, Y., Yokoyama, T., Yamashita, J., and Esumi, H. (1994) Expression of two types of nitric oxide synthase mRNA in human neuroblastoma cell lines. J. Neurochem. 63(1):140-145.

Fulda, S. (2009) The PI3K/Akt/mTOR pathway as therapeutic target in neuroblastoma. Curr Cancer Drug Targets 9: 729-737.

Garcia-Lora, A., Algarra, I., Collado, A., and Garrido, F. (2003) Tumor immunology, vaccination and escape strategies. Eur. J. Immunogenet. 30:177-183.

Giorgi, M., Leonetti, C., Citro, G., and Augusti-Tocco, G. (2001) In vitro and in vivo inhibition of SK-N-MC neuroblastoma growth using cyclic nucleotide phosphodiesterase inhibitors. J. Neuro-Oncol. 51(1):25-31.

Goillot, E., Combaret, V., Landenstein, R., Baubet, D., Blay, J-Y., Thierry, P. and Favrot, M.C. (1992) Tumor necrosis factor functions as an autocrine growth factor for neuroblastomas. Cancer Res. 52:3194-3200.

Gutierrez, L., and Magee, A.I. (1991) Characterization of an acyltransferase acting on p21 $\mathrm{N}$-ras protein in a cell-free system. Biochim. Biophys. Acta 1078: 147-154.

Hero, B., Simon, T., Spitz, R., Ernestus, K., Gnekow, A.K., Scheel-Walter, H.-G., Schwabe, D., Schilling, F.H., Benz-Bohm, G., and Berthold, F. (2008) Localized infant neuroblastomas often show spontaneous regression: results of the prospective trials NB95-S and NB97. J. Clin. Oncol. 26(9): 1504-1510.

Holzel, M., Huang, S., Koster, J., Ora, I., Lakeman, A., Caron, H., Nijkamp, W., Xie, J., Callens, T., Asgharzadeh, S., Seeger, R.C., Messiaen, L., Versteeg, R., and Bernards, R. (2010) NF1 is a tumor suppressor in neuroblastoma that determines retinoic acid response and disease outcome. Cell 142(2): 218-229.

Hopkins-Donaldson, S., Yan, P., Bourloud, K.B., Muhlethaler, A., Bodmer, J.L., and Gross, N. (2002) Doxorubicin-induced death in neuroblastoma does not involve death receptors in S-type cells and is caspase-independent in N-type cells. Oncogene 21(39): 6132-6137.

Howard, J.P., Maris, J.M., Kersun, L.S., Huberty, J.P., Cheng, S-C., Hawkins, R.A., and Matthay, K.K. (2005) Tumor response and toxicity with multiple infusions of high dose 131I-MIBG in refractory neuroblastoma. Ped. Blood E Cancer 44(3):232-239.

Jaboin, J., Kim, C.J., Kaplan, D.R., and Thiele, C.J. (2002) Brain-derived neurotrophic factor activation of TrkB protects neuroblastoma cells from chemotherapy-induced apoptosis via phosphatidylinositol 3'-kinase pathway. Cancer Res. 62: 6756-6763.

Jimenez-Andrade, J.M., Bloom, A.P., Stake, J.I., Mantyh, W. G., Taylor, R.N., Greeman, K.T., Ghilardi, J.R., Kuskowski, M.A., and Mantyh, P.W. (2010) Pathological sprouting of adult nociceptors in chronic prostate cancer-induced bone pain. J. Neurosci 30(44):14649-14656.

Kang. Y.-C., Kim, P.K., Choi, B.-M., Chung, H.-T., Ha, K.-S., Kwon, Y.-G., and Kim, Y.-M. (2004) Regulation of programmed cell death in neuronal cells by nitric oxide. In Vivo 18: 367-376. 
Kapoor, A., and Figlin, R.A. (2009) Targeted inhibition of mammalian target of rapamycin for the treatment of advanced renal cell carcinoma. Cancer 115(16): 3618-3630.

Kasahara, K., Nakayama, Y., Kihara, A., Matsuda, D., Ikeda, K., Kuga, T., Fukumoto, Y., Igarashi, Y., and Yamaguchi, N. (2007) Rapid trafficking of c-Src, a nonpalmitoylated Src-family kinase, between the plasma membrane and late endosomes/lysosomes. Exp. Cell Res. 313(12): 2651-2666.

Kilic, M., Schafer, R., Hoppe, J., and Kagerhuber, U. (2002) Formation of noncanonical high molecular weight caspase- 3 and -6 complexes and activation of caspase- 12 during serum starvation induced apoptosis in AKR-2B mouse fibroblasts. Cell Death $\mathcal{E}$ Diff. 9(2):125-137.

Kimmelman, A.C., Nunez Rodriguez, N., and Chan, A.M. (2002) R-Ras3/M-Ras induces neuronal differentiation of PC12 cells through cell-type-specific activation of the mitogen-activated protein kinase cascade. Mol. Cell Biol. 22(16):5946-5961.

Kischkel, F.C., Hellbardt, S., Behrmann, I., Germer, M., Pawlita, M., Krammer, P.H., and Peter, M.E. (1995) Cytotoxicity-dependent APO-1 (Fas/CD95)-associated proteins form a death-inducing signaling complex (DISC) with the receptor. EMBO J. 14: $5579-5588$.

Kitanaka, C., Kato, K., Ijiri, R., Sakurada, K., Tomiyama, A., Noguchi, K., Nagashima, Y., Nakagawara, A., Momoi, T., Toyoda, Y., Kigasawa, H., Nishi, T., Shirouzu, M., Yokoyama, S., Tanaka, Y., and Kuchino, Y. (2002) Increased Ras expression and caspase-independent neuroblastoma cell death: possible mechanism of spontaneous neuroblastoma regression. J. Natl. Cancer Inst. 94(5): 358-368.

Koegl, M., Zlatkine, P., Ley, S.C., Courtneidge, S.A., and Magee, A.I. (1994) Palmitoylation of multiple Src-family kinases at a homologous N-terminal motif. Biochem. J. 303: 749753.

Kushner, B.H., LaQuaglia, M.P., Bonilla, M.A., Lindsley, K., Rosenfield, N., Yeh, S., Eddy, J., Gerald, W.L., Heller, G., and Cheung, N.-K.V. (1994) Highly effective induction therapy for stage 4 neuroblastoma in children over 1 year of age. J. Clin. Oncol. 12(12):2607-2613.

Laifenfeld, D., Klein, E., and Ben-Shachar, D. (2002) Norepinephrine alters the expression of genes involved in neuronal sprouting and differentiation: relevance for major depression and antidepressant mechanisms. J. Neurochem. 83: 1054-1064.

Lalli, G., and Hall, A. (2005) Ral GTPases regulate neurite branching through GAP-43 and the exocyst complex. J. Cell Biol. 171(5):857-869.

Li, Z., and Thiele, C.J. (2007) Targeting Akt to increase the sensitivity of neuroblastoma to chemotherapy: lessons learned from the brain-derived neurotrophic factor/TrkB signal transduction pathway. Expert Opin. Ther. Targets 11: 1611-1621.

Lieven, C.J., Millet, L.E., Hoegger, M.J., and Levin, L.A. (2007) Induction of axon and dendrite formation during early RGC-5 cell differentiation. Exp. Eye Res. 85(5):678683.

Liu, H., Ng, C.E.L., and Tang, B.L. (2002) Nogo-A expression in mouse central nervous system neurons. Neurosci. Lett. 328(3):257-260.

Ma, L., Cao, T.T., Kandpal, G., Warren, L., Fred Hess, J., Seabrook, G.R. and Ray, W.J. (2010) Genome-wide microarray analysis of the differential neuroprotective effects of antioxidants in neuroblastoma cells overexpressing the familial Parkinson's disease alpha-synuclein A53T mutation. Neurochem Res. 35(1): 130-142. 
Margaritora, S., Cesario, A., Porziella, V., Granone, P., Catassi, A., and Russo, P. (2005) Farnesyltransferase inhibitors: overview of their action and role in solid malignancy therapy. Lett. Drug Design \& Discov. 2:26-35.

Maris, J.M. (2010) Recent advances in neuroblastoma. N. Engl. J. Med. 362 (23): 2202-2211.

Maris, J.M., Mosse, Y.P., Bradfield, J.P., Hou, C., Monni, S., Scott, R.H., Asgharzadeh, S., Attiyeh, E.F., Diskin, S.J., Laudenslager, M., Winter, C., Cole, K.A., Glessner, J.T., Kim, C., Frackelton, E.C., Casalunovo, T., Eckert, A.W., Capasso, M., Rappaport, E.F., McConville, C., London, W.B., Seeger, R.C., Rahman, N., Devoto, M., Grant, S.F.A., Li, H. and Hakonarson, H.(2008) Chromosome 6p22 locus associated with clinically aggressive neuroblastoma. N. Engl. J. Med. 358: 2585-2593.

Martelli, A.M., Evangelisti, C., Chiarini, F., and McCubrey, J.A. (2010) The phosphatidylinositol 3-kinase/Akt/mTOR signaling network as a therapeutic target in acute myelogenous leukemia patients. Oncotarget. 1(2):89-103.

McCombe, P. and Kidson, C. (1975) A repressible DNA-repair system in mouse neuroblastoma cells. Basic Life Sci. 5B: 813-815.

Milam, M.R., Gabel, S.F., Milam, R.A., Liu, J., and Ramirez, P.T. (2007) Neoadjuvant bleomycin, etoposide, and cisplatin in adult neuroblastoma arising from the broad ligament of the uterus. Gynecol. Oncol. 107(2): 350-354.

Moriya, R., Uehara, T., and Nomura, Y. (2000) Mechanism of nitric oxide-induced apoptosis in human neuroblastoma SH-SY5Y cells. FEBS Lett. 484(3): 253-260.

Mosse, Y.P., Laudenslager, M., Longo, L., Cole, K.A., Wood, A., Attiyeh, E.F., Laquaglia, M.J., Sennett, R., Lynch, J.E., Perri, P., Laureys, G., Speleman, F., Kim, C., Hou, C., Hakonarson, H., Torkamani, A., Schork, N.J., Brodeur, G.M., Tonini, G.P., Rappaport, E., Devoto, M., and Maris, J.M. (2008) Identification of ALK as a major familial neuroblastoma predisposition gene. Nature 455 (7215):930-935.

Mosse, Y.P., Wood, A., and Maris, J.M. (2009) Inhibition of ALK signaling for cancer therapy. Clin. Cancer Res. 15 (18): 5609-5614.

Munoz, J., Lazcoz, P., Inda, M.M., Nistal., M., Pestana, A., Encio, I.J., and Castresana, J.S. (2004) Homozygous deletion and expression of PTEN and DMBT1 in human primary neuroblastoma and cell lines. Int. J. Cancer 109:673-679.

Nakazawa, T., Tamai, M., and Mori, N. (2002) Brain-derived neurotrophic factor prevents axotomized retinal ganglion cell death through MAPK and PI3K pathways. Invest Ophthalmol. Vis. Sci.43(10):3319-3326.

Naumann, I., Kappler, R., von Schweinitz, D., Debatin, K.-M., and Fulda, S. (2011) Bortezomib primes neuroblastoma cells for TRAIL-induced apoptosis by linking the death receptor to the mitochondrial pathway. Clin. Cancer Res. 17(10): 32043218.

Navid, F., Santana, V.M., and Barfield, R.C. (2010) Anti-GD2 antibody therapy for GD2expressing tumors. Curr. Cancer Drug Targets 10(2):200-209.

Nicolini, G., Rigolio, R., Miloso, M., Bertelli, A.A.E., and Tredici, G. (2001) Anti-apoptotic effect of trans-resveratrol on paclitaxel-induced apoptosis in the human neuroblastoma SH-SY5Y cell line. Neurosci. Lett. 302 (1): 41-44.

Niizuma, H., Nakamura, Y., Ozaki, T., Nakanishi, H., Ohira, M., Isogai, E., Kageyama, H., Imaizumi, M., and Nakagawara, A. (2006) Bcl-2 is a key regulator for the retinoic acid-induced apoptotic cell death in neuroblastoma. Oncogene 25: 5046-5055. 
Ogbomo, H., Hahn, A., Geiler, J., Michaelis, M., Doerr, H.W., and Cinatl, J.Jr. (2006) NK sensitivity of neuroblastoma cells determined by a highly sensitive coupled luminescent method. Biochem. Biophys. Res. Commun. 339: 375-379.

Oh, J.-E., Karlmark, K.R., Shin, J.-H., Pollak, A., Freilinger, A., Hengstschlager, M., and Lubec, G. (2005) Differentiation of neuroblastoma cell line N1E-115 involves several signaling cascades. Neurochem. Res. 30(3):333-348.

Oh, J.-E., Karlmark, K.R., Shin, J.-H., Pollak, A., Hengstschlager, M., and Lubec, G. (2006) Cytoskeleton changes following differentiation of N1E-115 neuroblastoma cell line. Amino Acids 31(3):289-293.

Ollom, C.M., and Denny. J.B. (2008) A crosslinking analysis of GAP-43 interactions with other proteins in differentiated N1E-115 cells. Int. J. Mol. Sci. 9: 1753-1771.

Omer, C.A., Anthony, N.J., Buser-Doepner, C.A., Burkhardt, A.L., deSolms, S.J., Dinsmore, C.J., Gibbs, J.B., Hartman, G.D., Koblan, K.S., Lobell, R.B., Oliff, A., Williams, T.M., and Kohl, N.E. (1997) Farnesyl:proteintransferase inhibitors as agents to inhibit tumor growth. Biofactors 6(3):359-366.

Pappolla, M.A., Sos, M., Omar, R.A., Bick, R.J., Hickson-Bick, D.L.M., Reiter, R.J., Efthimiopoulos, and Robakis, N.K. (1997) Melatonin prevents death of neuroblastoma cells exposed to the Alzheimer amyloid peptide. J. Neurosci. 17(5): 1683-1690.

Peterson, T.R., Laplante, M., Thoreen, C.C., Sancak, Y., Kang, S.A., Kuehl, W.M., Gray, N.S., and Sabatini, D.M. (2009) DEPTOR is an mTOR inhibitor frequently overexpressed in multiple myeloma cells and required for their survival. Cell 137: 873-886.

Petroni, M., Veschi, V., Prodosmo, A., Rinaldo, C., Massimi, I., Carbonari, M., Dominici, C., McDowell, H.P., Rinaldi, C., Screpanti, I., Frati, L., Bartolazzi, A., Gulino, A., Soddu, S., and Giannini, G. (2011) MYCN sensitizes human neuroblastoma to apoptosis by HIPK2 activation through a DNA damage response. Mol. Cancer Res. 9(1): 67-77.

Philips, M.R., and Cox, A.D. (2007) Geranylgeranyltransferase I as a target for anti-cancer drugs. J. Clin. Invest. 117(5):1223-1225.

Plantaz, D., Mohapatra, G., Matthay, K.K., Pellarin, M., Seeger, R.C., and Feurerstein, B.G. (1997) Gain of chromosome 17 is the most common abnormality detected in neuroblastoma by comparative genomic hybridization. Am. J. Pathol.150(1):81-89.

Prince, J.A., and Oreland, L. (1997) Staurosporine differentiated human SH-SY5Y neuroblastoma cultures exhibit transient apoptosis and trophic factor independence. Brain Res. Bull. 43(6):515-523.

Pritchard, J., Cotterill, S.J., Germond, S.M., Imeson, J., de Kraker, J., and Jones, D.R. (2005) High dose melphalan in the treatment of advanced neuroblastoma: results of a randomised trial (ENSG-1) by the European Neuroblastoma Study Group. Pediatr. Blood Cancer 44(4):348-357.

Reagan, L.P., Ye, X.R., Mir, R., DePalo, L.R., and Fluharty, S.J. (1990) Up-regulation of angiotensin II receptors by in vitro differentiation of murine N1E-115 neuroblastoma cells. Mol. Pharmacol. 38(6): 878-886.

Reid, G.S.D., Shan, X., Coughlin, C.M., Lassoued, W., Pawel, B.R., Wexler, L.H., Thiele, C.J., Tsokos, M., Pinkus, J.L., Pinkus, G.S., Grupp, S.A., and Vonderheide, R.H. (2009) Interferon- $\gamma$-dependent infiltration of human $\mathrm{T}$ cells into neuroblastoma tumors in vivo. Clin. Cancer Res. 15(21):6602-6608. 
Ribatti, D., Marimpietri, D., Pastorino, F., Brignole, C., Nico, B., Vacca, A., and Ponzoni, M. (2004) Angiogenesis in neuroblastoma. Ann. N.Y. Acad. Sci. 1028:133-142.

Sarbassov, D.D., Ali, S.M., and Sabatini, D.M. (2005) Growing roles for the mTOR pathway. Curr. Opin. Cell Biol. 17: 596-603.

Sartelet, H., Oligny, L.L., and Vassal, G. (2008) AKT pathway in neuroblastoma and its therapeutic implication. Expert Rev. Anticancer Ther. 8(5): 757-769.

Song, L., Ara, T., Saio, J., Deng, Z-b., Asgharzdeh, S., Ji, L., Sposto, R., DeClerck, Y.A., Seeger, R.C. and Metelitsa, L.S. (2007) The role of paracrine IL-6 and IL-10 in neuroblastoma progression. J. Immunol. 178:49.9.

Steelman, L.S., Abrams, S.L., Whelan, J., Bertrand, F.E., Ludwig, D.E., Basecke, J., Libra, M., Stivala, F., Milella, M., Tafuri, A., Lunghi, P., Bonati, A., Martelli, A.M., and McCubrey, J.A. (2008) Contributions of the Raf/MEK/ERK, PI3K/PTEN/Akt/mTOR and Jak/STAT pathways to leukemia. Leukemia 22:686707.

Steelman, L.S., Pohnert, S.C., Shelton, J.G., Franklin, R.A., Bertrand, F.E., and McCubrey, A. (2004) JAK/STAT, Raf/MEK/ERK, PI3K/Akt and BCR-ABL in cell cycle progression and leukemogenesis. Leukemia 18:189-218.

Streck, C.J., Zhang, Y., Miyamoto, R., Zhou, J., Ng, C.Y., Nathwani, A.C., and Davidoff, A.M. (2004) Restriction of neuroblastoma angiogenesis and growth by interferonalpha/beta. Surgery 136(2):183-189.

Takeda, M., Kobayashi, M., Osaki, T., Shirato, I., and Endou, H. (1997) Staurosporineinduced apoptosis of immortalized mouse proximal tubule cells is modulated by bcl-2 expression level. Int. Union of Biochem. Mol. Biol. Life 42: 649-656.

Tchedre, K.T., and Yorio, T. (2008) $\alpha-1$ receptors protect RGC-5 cells from apoptosis by regulating intracellular calcium, bax levels, and caspase-3 activation. Invest. Ophthal. Vis. Sci. 49:2577-2588.

Tokunaga, E., Oki, E., Egashira, A., Sadanaga, N., Morita, M., Kakeji, Y., and Maehara, Y. (2008) Deregulation of the Akt pathway in human cancer. Curr. Cancer Drug Targets $8(1): 27-36$.

Tweddle, D.A., Pearson, A.D.J., Haber, M., Norris, M.D., Xue, C., Flemming, C., and Lunec. J. (2003) The p53 pathway and its inactivation in neuroblastoma. Cancer Lett. 197(1): 93-98.

Wang, X., Bauer, J.H., Li, Y., Shao, Z., Zetoune, F.S., Cattaneo, E., and Vincenz, C. (2001) Characterization of a p75 (NTR) apoptotic signaling pathway using a novel cellular model. J. Biol. Chem. 276(36): 33812-33820.

Wickstrom, M., Johnsen, J.I., Ponthan, F., Segerstrom, L., Sveinbjomsson, B., Lindskog, M., Lovborg, H., Viktorsson, K., Lewensohn, R., Kogner, P., Larsson, R., and Gullbo, J. (2007) The novel melphalan prodrug J1 inhibits neuroblastoma growth in vitro and in vivo. Mol. Cancer Ther. 6: 2409-2417.

Wolfl, M., Jungbluth, A.A., Garrido, F., Cabrera, T., Meyen-Southard, S., Spitz, R., Ernestus, K., and Berthold, F. (2005) Expression of MHC class I, MHC class II, and cancer germline antigens in neuroblastoma. Cancer Immunol. Immunother. 54:400-406.

Wu, J., DiPietrantonio, A., and Hsieh, T. (2001) Mechanism of fenretinide (4-HPR)-induced cell death. Apoptosis 6(5):377-388. 
Yang, H., Shaw, G., and Raizada, M.K. (2002) ANG II stimulation of neuritogenesis involves protein kinase B in brain neurons. Am. J. Physiol. Regul. Integr. Comp. Physiol. 283:R107-R114.

Yoshida, H., Enomoto, H., Miyauchi, M., Takanaga, K., Ohnuma, N., Sakiyama, S., and Tagawa, M. (1998) Impaired tumorigenicity of IL-4 produciing murine neuroblastoma cells in immunodeficient nude mice. Int. J. Oncol. 12(5);1067-1071.

Yu, A.L., Gilman, A., Ozkaynak, F., London, W.B., Kreissman, S., Chen, H.X., Smith, M., Anderson, B., Villablanca, J., Matthay, K.K., Shimada, H., Grupp, S.A., Seeger, R., Reynolds, P., Buxton, A., Reisfeld, R.A., Gillies, S.D., Cohn, S.L., Maris, J.M., and Sondel, P.M. (2010) Anti-GD2 antibody with GM-CSF, interleukin-2, and isotretinoin for neuroblastoma. N. Engl. J. Med. 363: 1324-1334.

Zagrebelsky, M., Schweigreiter, R., Bandtlow, C.E., Schwab, M.E. and Korte, M. (2010) Nogo-A stabilizes the architecture of hippocampal neurons. J. Neurosci. 30(40): 13220-13234.

Zechel, C. (2005) Requirement of retinoic acid receptor isotypes $\alpha, \beta$, and $\gamma$ during the initial steps of neural differentiation of PCC7 cells. Mol. Endocrinol. 19(6): 1629-1645.

Zheng, L., Jo, J., Jia, J.-M., Lo, S.-C., Whitcomb, D.J., Jiao, S., Cho, K., and Sheng, M. (2010) Caspase-3 activation via mitochondria is required for long-term depression and AMPA receptor internalization. Cell 141(5): 859-871 


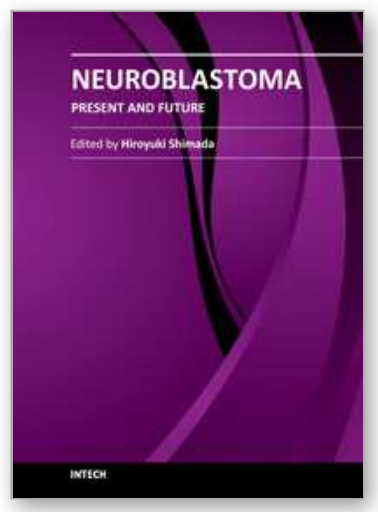

\author{
Neuroblastoma - Present and Future \\ Edited by Prof. Hiroyuki Shimada
}

ISBN 978-953-307-016-2

Hard cover, 366 pages

Publisher InTech

Published online 08, February, 2012

Published in print edition February, 2012

Neuroblastoma, once called "enigmatic", due to "unpredictable" clinical behaviors, is composed of biologically diverse tumors. Molecular/genomic properties unique to the individual tumors closely link to the clinical outcomes of patients. Establishing risk stratification models after analyzing biologic characteristics of each case has made a great success in patient management. However, the trend of improving survival rates in neuroblastoma over the last 30 years has started to level off, and currently available treatment modalities have almost reached to their maximized intensity. Furthermore, aggressive treatment causes significant long-term morbidities to the survivors. We really need to make the next step to the level of personalized medicine with more precise understanding of neuroblastoma biology. This book includes useful data and insights from the world's experts in this field. I believe this book can make an excellent contribution to all the investigators working hard and fighting for the children stricken by this disease.

\title{
How to reference
}

In order to correctly reference this scholarly work, feel free to copy and paste the following:

John B. Denny (2012). The Cell Biology of Neuroblastoma, Neuroblastoma - Present and Future, Prof. Hiroyuki Shimada (Ed.), ISBN: 978-953-307-016-2, InTech, Available from:

http://www.intechopen.com/books/neuroblastoma-present-and-future/the-cell-biology-of-neuroblastoma

\section{INTECH}

open science | open minds

\author{
InTech Europe \\ University Campus STeP Ri \\ Slavka Krautzeka 83/A \\ 51000 Rijeka, Croatia \\ Phone: +385 (51) 770447 \\ Fax: +385 (51) 686166 \\ www.intechopen.com
}

\author{
InTech China \\ Unit 405, Office Block, Hotel Equatorial Shanghai \\ No.65, Yan An Road (West), Shanghai, 200040, China \\ 中国上海市延安西路65号上海国际贵都大饭店办公楼 405 单元 \\ Phone: +86-21-62489820 \\ Fax: +86-21-62489821
}


(C) 2012 The Author(s). Licensee IntechOpen. This is an open access article distributed under the terms of the Creative Commons Attribution 3.0 License, which permits unrestricted use, distribution, and reproduction in any medium, provided the original work is properly cited. 